\title{
Colletotrichum spp. causing anthracnose on ornamental plants in northern Italy
}

\author{
Vladimiro Guarnaccia ${ }^{1,2}$ (D) - Ilaria Martino ${ }^{1}$. Giovanna Gilardi ${ }^{1}$. Angelo Garibaldi ${ }^{1}$ M. Lodovica Gullino ${ }^{1,2}$
}

Received: 3 May 2020 / Accepted: 9 October 2020 / Published online: 21 October 2020

(C) The Author(s) 2020

\begin{abstract}
Species of Colletotrichum are considered among the most important plant pathogens, saprobes and endophytes on a wide range of ornamentals, fruits and vegetables. Several Colletotrichum species have been reported in nurseries and public or private gardens in northern Italy. In this study, the occurrence, diversity and pathogenicity of Colletotrichum spp. associated with several ornamental hosts was explored. Survey were carried out during the 2013-2019 period in Piedmont, Italy. A total of 22 Colletotrichum isolates were collected from symptomatic leaves and stems of two Campanula spp., Ceanothus thyrsiflorus, Coreopsis lanceolata, Cyclamen persicum, Hydrangea paniculata, Liquidambar styraciflua, Mahonia aquifolium and Rhyncospermum jasminoides. A multi-locus phylogeny was established based on the basis of three genomic loci (gapdh, act and $t u b 2$ ). The pathogenicity of selected, representative isolates was tested. Colletotrichum isolates were identified as members of four important species complexes: Acutatum, Gloeosporioides, Dematium and Destructivum. Colletotrichum fioriniae, C. nymphaeae and C. fuscum were found in association with leaf lesions of Mahonia aquifolium, Campanula rapunculoides and Coreopsis lanceolata, respectively. Colletotrichum lineola, C. grossum and C. cigarro were isolated from Campanula trachelium, Rhyncospermum jasminoides and Liquidambar styraciflua, respectively. Colletotrichum fructicola was found to be responsible of anthracnose of Ceanothus thyrsiflorus, Hydrangea paniculata, Cyclamen persicum and Liquidambar styraciflua. All the tested isolates were pathogenic and reproduced identical symptoms to those observed in private gardens and nurseries. The present study improves our understanding of Colletotrichum spp. associated with different ornamental hosts and provides useful information for an effective disease management programme.
\end{abstract}

Keywords Leaf spot $\cdot$ Multi-locus sequence typing $\cdot$ Pathogenicity $\cdot$ Species complex

\section{Introduction}

The genus Colletotrichum has been reported as one of the ten most important plant pathogens in the world based on economic importance (Dean et al. 2012). Anthracnose disease caused by species members of this genus could affect several plants from woody to herbaceous ones, producing significant economic losses in tropical, subtropical and temperate regions. They can develop on fruit, leaves, stems, tubers and

Vladimiro Guarnaccia

vladimiro.guarnaccia@unito.it

1 Centre for Innovation in the Agro-Environmental Sector, AGROINNOVA, University of Torino, Largo Braccini 2, TO 10095 Grugliasco, Italy

2 Department of Agricultural, Forest and Food Sciences (DISAFA), University of Torino, Largo Braccini 2, TO 10095 Grugliasco, Italy seedlings in the field or in greenhouse environment and it is also important as causing post-harvest disease on fruit and vegetables (Cannon et al. 2012; Damm et al. 2012a, b; Udayanga et al. 2013). Colletotrichum spp. show different lifestyles which can be generally classified as necrotrophic, hemibiotrophic, latent and endophytic (De Silva et al. 2017). Detection and control of diseases caused by Colletotrichum spp. could be difficult due to the complex life cycle of many species, to the ability to change lifestyle and to the potential cross infection of different plant hosts (O'Connell et al. 2012).

After the advent of the molecular era, the adoption of multigene phylogenetic analyses, combined with the traditional morphology-based identification methods, led to a deep revision within the taxonomy of this genus. Several major studies (Cannon et al. 2008; Cai et al. 2009; Damm et al. 2009; 2012a, b; 2013; 2014; Weir et al. 2012) significantly changed the classification and species concepts in Colletotrichum. Currently, 14 Colletotrichum species complexes (SC) and 
more than 24 singleton species have been identified (Cannon et al. 2012; Marin-Felix et al. 2017). In plant pathology, the most relevant species are part of the $C$. gloeosporioides (Cannon et al. 2008; Weir et al. 2012), C. acutatum (Shivas and Tan 2009; Damm et al. 2012a), C. boninense (Damm et al. 2012b) and C. truncatum (Damm et al. 2009; Cannon et al. 2012) species complexes. Moreover, the $C$. destructivum (Damm et al. 2009) and C. dematium (Damm et al. 2014) SC includes important plant pathogens.

Ornamental plants include flowering, bedding potted and garden plants, evergreen and deciduous trees, foliage plants, woody ornamentals, shrubs, herbaceous perennials and cut flowers along with nursery crops, cut cultivated greens and propagation material (Gullino and Garibaldi 2007; Chase et al. 2018). Ornamental plants are usually cultivated in gardens and for commercial purpose, which has increased globally over the past few decades. In Italy, the value of floriculture amounts to more than 2.5 billion euros, half of which comes from the production of flowers and potted plants. There are 27 thousand companies involved in the sector, distributed in almost 29,000 hectares of agricultural land overall (Croci 2018). During the last several decades, this sector has passed through different technological changes, such as environmental and nutrition controls, which have pushed plants to their limits of growth and productivity. Thus, new limiting factors have been generated related to disease occurrence and management, and ornamental plants are more conducive to several pathogens and diseases (Guarnaccia et al. 2014; Gullino et al. 2015).

Several Colletotrichum spp. have been detected on ornamental plants from southern to northern Italy (Polizzi et al. 2011; Camele et al. 2018; Guarnaccia et al. 2019; Gilardi et al. 2015; Garibaldi et al. 2016) and particular environmental conditions, such as high humidity and temperature, play a major role in development and sporulation of these pathogens (Cannon et al. 2012).

The present study refers to anthracnose symptoms detected on nine different ornamental host plants: Liquidambar styraciflua (American sweetgum), Ceanothus thyrsiflorus (blue blossom), Hydrangea paniculata (hortensia), Cyclamen persicum (cyclamen), Rhyncospermum jasminoides (star jasmine), Mahonia aquifolium (Oregon grape), Coreopsis lanceolata (lanceleaf coreopsis) and two Campanula spp. (campanula).

Cyclamen persicum is a flowering herbaceous perennial, appreciated as an indoor plant cultivated for its attractive white to pink to deep red flowers (Takamura 2007). American sweetgum (L. styraciflua) is a deciduous tree, native to North America and popular as ornamental tree in temperate climates (Brand and Lineberger 1992). Coreopsis lanceolata and Campanula spp. are perennial plants, largely cultivated in borders or gardens and usually planted in mass or groups, known as bedding plants (Lee 2012; Scariot et al. 2012).
Rhyncospermum jasminoides is an evergreen woody, climbing liana (Weaver and Anderson 2012). Hortensia is a deciduous shrub native to China and Japan (Lancaster and Wesley 2008), whilst, C. thyrsiflorus and M. aquifolium are evergreen shrubs. These bushes are used in mixed shrub borders or in open woodland gardens (Schmidt 2006; Garibaldi et al. 2020).

Thus, considering the important value of ornamental crops, the relevance of this agriculture sector in Italy and the impact of Colletotrichum spp. on these hosts, surveys were conducted over a 5 -year period in Northern Italy. The aims of this study were: (i) to characterize species of Colletotrichum isolated from ornamentals hosts combining multi-locus phylogenetic analysis with morphological features and (ii) to evaluate the pathogenicity of Colletotrichum species on the host plants from which they were isolated.

\section{Material and methods}

\section{Field surveys and fungal isolation}

Samples were obtained from symptomatic plants grown in a private garden near Biella in Northern Italy $\left(45^{\circ} 36^{\prime} \mathrm{N} 8^{\circ} 03^{\prime} \mathrm{E}\right)$ and in a nursery specialized in the production and sale of young ornamentals in northern Italy, with appropriate permissions. The garden is subjected to the continuous survey as a representative site exposed to the introduction of new plant pests, being cultivated several exotic plants.

Anthracnose symptoms consisting of brown to black lesions were detected on leaves of two Campanula spp., Ce. thyrsiflorus (blue blossom), Cor. lanceolata, Cy. persicum, H. paniculata (hortensia), L. styraciflua (American sweetgum), M. aquifolium (Oregon grape), $R$. jasminoides and on stem and leaves of Cy. persicum between 2013-2019 period. During the field survey, the disease incidence was recorded.

Samples from around 20 plants per species which showed anthracnose were randomly collected. Small sections $(0.2-$ $0.5 \mathrm{~cm}$ long) from the lesion margin were surface disinfected with $1 \%$ sodium hypochlorite for $1 \mathrm{~min}$, then rinsed once in sterile distilled water (SDW), dried on sterile paper and placed on potato dextrose agar (PDA, Oxoid, Basingstoke, England) plates amended with $25 \mathrm{ppm}$ streptomycin sulphate (PDA + A. Sigma-Aldrich, St. Louis, MO, USA). The plates were incubated at $25 \pm 1{ }^{\circ} \mathrm{C}$ under a $12 \mathrm{~h}$ photoperiod. After an incubation of 48 to $72 \mathrm{~h}$, hyphae from the margin of the colonies resembling Colletotrichum spp. were placed on PDA plates. Five days later, single spores were transferred into PDA plates to establish pure cultures.

A total of 22 isolates were obtained and used for molecular characterization (Table 1). Stock cultures are maintained in 
$15 \%$ glycerol solution at $-80{ }^{\circ} \mathrm{C}$ in the Agroinnova (University of Torino) culture collection, Torino, Italy.

\section{DNA extraction, PCR amplification and sequencing}

Total DNA was extracted for all Colletotrichum isolates using the E.Z.N.A. ${ }^{\circledR}$ Fungal DNA Mini Kit (Omega Bio-Tek, Darmstadt, Germany), following the manufacturer's instructions. Partial regions of three loci were amplified. The partial glyceraldehyde-3-phosphate dehydrogenase (gapdh), actin $(a c t)$ and beta-tubulin (tub2) genes were amplified using GDF1 and GDR1 (Guerber et al. 2003), ACT-512F and ACT-783R (Carbone and Kohn 1999), and T1 (Glass and Donaldson 1995) and Bt-2b (O'Donnell and Cigelnik 1997) primers, respectively. The amplification mixtures of polymerase chain reaction (PCR) and relative cycling conditions were adopted for all three loci according to Guarnaccia et al. (2019). PCR products were sequenced by Eurofins Genomics Service (Ebersberg, Germany). The generated sequences were analysed and assembled with the program Geneious v. 11.1.5 (Auckland, New Zealand).

\section{Phylogenetic analyses}

The sequences obtained in this study were analysed using the NCBIs GenBank database through the "BLAST" command, then compared with reference sequences downloaded from GenBank, aligned by using the MAFFT v. 7 online servers (http://mafft.cbrc.jp/alignment/server/index.html) (Katoh and Standley 2013) and then manually adjusted in MEGA v. 7 (Kumar et al. 2016). The analyses were conducted for individual locus (data not shown) and as concatenated analyses of three loci with the aim to identify the isolates to the species level. Additional reference sequences were selected based on recent studies on Colletotrichum species (Damm et al. 2009; 2012a, b; Weir et al. 2012; Guarnaccia et al. 2017). The phylogeny was developed based on Maximum Parsimony (MP) for all individual loci, and based on both MP and Bayesian Inference (BI) for the combined multilocus analyses. For BI, the best evolutionary model was suggested by MrModeltest $\mathrm{v}$. 2.3 (Nylander 2004) for each partition. MrBayes v. 3.2.5 (Ronquist et al. 2012) was used to obtain phylogenetic trees with optimal criteria per partition. The Markov Chain Monte Carlo (MCMC) analysis used four chains and started from a random tree topology. The heating parameter was established at 0.2 and trees were sampled every 1000 generations. The analyses were considered done when the average standard deviation of split frequencies was less than 0.01. The MP analyses were conducted using PAUP (Swofford 2003). Phylogenetic relationships were estimated by heuristic searches with 100 random additional sequences. Tree bisection-reconnection was adopted, with the branch swapping option set at 'best trees' only with all characters weighted equally and alignment gaps treated as fifth state. Tree length (TL), consistency index (CI), retention index (RI) and rescaled consistency index (RC) were calculated to set the parsimony and the bootstrap analyses (Hillis and Bull 1993) were based on 1000 replications. Sequences generated in this study were deposited in GenBank (Table 1).

\section{Morphology}

Agar plugs (5-mm-diam) of representative strains were taken from the edge of 10-day-old cultures and transferred to the centre of 9-cm-diam Petri dishes containing PDA. Plates were incubated at $25 \pm 1{ }^{\circ} \mathrm{C}$ under $12 \mathrm{~h}$ photoperiod for $10 \mathrm{~d}$. Three cultures plates of each isolate were investigated. Colony characters, colors and diameter were observed/measured after 10 d. Cultures were examined over time for ascomata, conidiomata and setae development. The morphological characteristics were examined by mounting fungal structures in water and 30 measurements at $400 \mathrm{X}$ magnification were determined for each isolate using a Nikon Eclipse 55i microscope.

\section{Pathogenicity}

One representative isolate of each Colletotrichum species identified was selected and inoculated on the same host that was isolated. The isolates were grown on PDA with streptomycin sulphate $(25 \mathrm{mg} / \mathrm{L})$ and kept at $25^{\circ} \mathrm{C}$ with a $12 \mathrm{~h}$ photoperiod for 7 days.

Five 1-year old plants for each plant species were used. Leaves of the plant hosts were sprayed with conidia suspensions (final concentration of $10^{6}$ conidia $/ \mathrm{ml}$ ). The pathogenicity trials were established both on wounded and unwounded leaves. Leaves were wounded at the centre of the adaxial surface using a sterile needle. SDW and sterile PDA plugs (5 mm diam) were used for control plants. The plants were covered with a transparent plastic film to keep a high level of relative humidity $(\mathrm{RH})$ and kept in a growth chamber at $25{ }^{\circ} \mathrm{C}$ with a $12 \mathrm{~h}$ photoperiod. The plastic film was removed three days postinoculation (dpi). The trial was repeated once. A disease severity (DS) index was adopted to rank the plants after 7 to $10 \mathrm{dpi}$ according to these values: 0 indicated healthy plants, 25, low virulent lesions and slight leaf chlorosis, 50 , moderate presence of typical anthracnose on leaves, 100 , high presence of necrotic spots and dead plants. The pathogen aggressiveness for each host was classificated as = Low L (disease index 0-25); Average $=\mathrm{M}$ (disease index 26 -50$)$; High $\mathrm{H}$ (disease index $>51$ ) (Guarnaccia et al. 2019). The inoculated fungi were re-isolated and identified by sequencing the gapdh locus, thus fulfilling Koch's postulates. 
Table 1 Collection details of Colletotrichum isolates, aggressiveness expressed after the pathogenicity test and GenBank accession numbers of other Colletotrichum isolates included in this study

\begin{tabular}{|c|c|c|c|c|c|c|c|}
\hline Species & Culture No. ${ }^{1}$ & Host & Locality & Aggressiveness & $\begin{array}{l}\text { GenBank } \\
\text { No. }^{2} \\
\text { gapdh }\end{array}$ & tub2 & $a c t$ \\
\hline C. abscissum & $\operatorname{COAD} 1877^{\mathrm{T}}$ & Citrus sinensis & Brazil & - & KP843129 & KP843135 & KP843141 \\
\hline C. acutatum & CBS $112996^{\mathrm{T}}$ & Carica papaya & Australia & - & JQ948677 & JQ005860 & JQ005839 \\
\hline C. antirrhinicola & CBS $102189^{\mathrm{T}}$ & Antirrhinum majus & New Zeland & _ & KM105531 & KM105460 & KM105390 \\
\hline C. boninense & CBS $123755^{\mathrm{T}}$ & $\begin{array}{l}\text { Crinum asiaticum var } \\
\text { sinicum }\end{array}$ & Japan & - & JQ005240 & JQ005588 & JQ005501 \\
\hline C. brisbanense & CBS $292.67^{\mathrm{T}}$ & Capsicum annuum & Australia & - & JQ948621 & JQ949942 & JQ949612 \\
\hline C. bryoniicola & CBS 109849 & Bryonia dioica & Netherlands & _ & KM105532 & KM105461 & KM105391 \\
\hline C. chrysanthemi & CBS 126519 & $\begin{array}{l}\text { Chrysanthemum } \\
\text { coronarium }\end{array}$ & Netherlands & - & JQ948602 & JQ949923 & JQ949593 \\
\hline \multirow[t]{2}{*}{ C. cigarro } & ICMP $18539^{\mathrm{T}}$ & Olea europaea & Australia & _- & JX009966 & JX010434 & JX009523 \\
\hline & CVG217* & Liquidambar styraciflua & Italy & M & MT292042 & MT292081 & MT292062 \\
\hline C. circinans & CBS $221.81^{\mathrm{T}}$ & Allium cepa & Serbia & - & GU228247 & GU228149 & GU227953 \\
\hline C. citri & CBS $134233^{\mathrm{T}}$ & Citurs aurantiifolia & China & _- & KC293741 & KC293661 & KC293621 \\
\hline C. coccodes & CBS 126378 & Solanum tuberosum & South Africa & _- & JX546739 & JX546882 & JX546643 \\
\hline C. conoides & CGMCC $3.17615^{\mathrm{T}}$ & Capsicum annuиm & China & _- & KP890162 & KP890174 & KP890144 \\
\hline \multirow[t]{3}{*}{ C. dematium } & IMI 350847 & Solanum tuberosum & Australia & _- & GU228217 & GU228119 & GU227923 \\
\hline & CBS 125340 & Apiaceae & Czech Republic & _ & GU228212 & GU228114 & GU227918 \\
\hline & CBS 125.5 & Eryngium campestre & France & - & GU228211 & GU228113 & GU227917 \\
\hline C. destructivum & CBS 136228 & Crupina vulgaris & Greece & _- & KM105574 & KM105499 & KM105429 \\
\hline \multirow[t]{4}{*}{ C. fioriniae } & ATCC 28992 & Malus domestica & USA & _ & JQ948627 & JQ949948 & JQ949618 \\
\hline & CBS 129916 & Vaccinium sp. & USA & _ & JQ948647 & JQ949968 & JQ949638 \\
\hline & CBS 293.67 & Persea americana & Australia & _ & JQ948640 & JQ949961 & JQ949631 \\
\hline & $19 / 18^{*}$ & Mahonia aquifolium & Italy & M & MT292057 & MN520416 & MN520417 \\
\hline \multirow[t]{16}{*}{ C. fructicola } & $\begin{array}{l}\text { ICMP } 18581, \text { CBS } \\
130416^{\mathrm{T}}\end{array}$ & Coffea arabica & Thailand & - & JX010033 & JX010405 & FJ907426 \\
\hline & LC 2923 & Camellia sinensis & China & - & KJ954784 & KJ955232 & KJ954365 \\
\hline & CBS 238.49 & Ficus edulis & Germany & - & JX009923 & JX010400 & JX009495 \\
\hline & CVG $212 *$ & Ceanothus thrysiflorus & Italy & $\mathrm{H}$ & MT292041 & MT292080 & MT292061 \\
\hline & CVG 218 & Liquidambar styraciflua & Italy & M & MT292043 & MT292082 & MT292063 \\
\hline & CVG 220 & Liquidambar styraciflua & Italy & _- & MT292044 & MT292083 & MT292064 \\
\hline & CVG $221 *$ & Liquidambar styraciflua & Italy & _- & MT292045 & MT292084 & MT292065 \\
\hline & CVG 224* & Hydrangea paniculata & Italy & $\mathrm{L}$ & MT292046 & MT292085 & MT292066 \\
\hline & CVG 225 & Hydrangea paniculata & Italy & & MT292047 & MT292086 & MT292067 \\
\hline & CVG $270^{*}$ & Cyclamen persicum & Italy & M & MT292048 & MT292087 & MT292068 \\
\hline & CVG 271 & Cyclamen persicum & Italy & _ & MT292049 & MT292088 & MT292069 \\
\hline & CVG 272 & Cyclamen persicum & Italy & _ & MT292050 & MT292089 & MT292070 \\
\hline & CVG 273 & Cyclamen persicum & Italy & _ & MT292051 & MT292090 & MT292071 \\
\hline & CVG 274 & Cyclamen persicum & Italy & _ & MT292052 & MT292091 & MT292072 \\
\hline & CVG 275 & Cyclamen persicum & Italy & _ & MT292053 & MT292092 & MT292073 \\
\hline & CVG 276 & Cyclamen persicum & Italy & _ & MT292054 & MT292093 & MT292074 \\
\hline \multirow[t]{2}{*}{ C. fuscum } & CBS $133701^{\mathrm{T}}$ & Digitalis lutea & Germany & _- & KM105524 & KM105454 & KM105384 \\
\hline & $62-1 *$ & Coreopsis lanceolata & Italy & M & MT013215 & $M N 615837$ & MN615838 \\
\hline C. gloeosporioides & $\begin{array}{l}\text { ICMP17821, CBS } \\
\quad 112999\end{array}$ & Citrus sinensis & Italy & - & JX010056 & JX010445 & JX009531 \\
\hline C. godetiae & CBS 133.44 & Clarkia hybrida & Denmark & - & JQ948733 & JQ950053 & JQ949723 \\
\hline C. grevilleae & CBSB $132879^{\mathrm{T}}$ & Grevillea sp. & Italy & - & KC297010 & KC297102 & KC296941 \\
\hline \multirow[t]{2}{*}{ C. grossum } & CGMCC $3.17614^{\mathrm{T}}$ & Capsicum annuum & China & - & KP890159 & KP890171 & KP890141 \\
\hline & CVG437* & & Italy & $\mathrm{L}$ & MT292055 & MT292094 & MT292075 \\
\hline
\end{tabular}


Table 1 (continued)

\begin{tabular}{|c|c|c|c|c|c|c|c|}
\hline Species & Culture No. ${ }^{1}$ & Host & Locality & Aggressiveness & $\begin{array}{l}\text { GenBank } \\
\text { No. }^{2} \\
\text { gapdh }\end{array}$ & tub2 & act \\
\hline & & $\begin{array}{l}\text { Rhyncospermum } \\
\text { jasminoides }\end{array}$ & & & & & \\
\hline & CVG443 & $\begin{array}{l}\text { Rhyncospermum } \\
\text { jasminoides }\end{array}$ & Italy & & MT292056 & - & MT292076 \\
\hline C. helleniense & $\begin{array}{l}\text { CBS } 142418, \text { CPC } \\
26844\end{array}$ & Pncirus trifoliata & Greece & - & KY856270 & KY856528 & KY856019 \\
\hline C. hemerocallidis & CBS $130642^{\mathrm{T}}$ & $\begin{array}{l}\text { Hemerocallis fulva var } \\
\quad \text { fulva }\end{array}$ & China & - & JQ400012 & JQ400019 & JQ399991 \\
\hline C. jiangxiense & CGMCC $3.17363^{\mathrm{T}}$ & Camellia sinensis & China & - & KJ954902 & KJ955348 & KJ95447 \\
\hline C. kahawae & ICMP 17816 & Coffea arabica & Kenya & _ & JX010012 & JX010444 & JX009452 \\
\hline \multirow[t]{4}{*}{ C. lineola } & CBS $125337^{\mathrm{T}}$ & Apiaceae & Czech Republic & - & GU228221 & GU228123 & GU227927 \\
\hline & CVG207* & Campanula trachelium & Italy & $\mathrm{L}$ & MT292038 & MT292077 & MT292058 \\
\hline & CVG208 & Campanula trachelium & Italy & - & MT292039 & MT292078 & MT292059 \\
\hline & CVG209 & Campanula trachelium & Italy & - & MT292040 & MT292079 & MT292060 \\
\hline C. lini & CBS $172.51^{\mathrm{T}}$ & Linum usitatissimum & Netherlands & - & KM105581 & JQ005849 & JQ005828 \\
\hline C. nigrum & CBS 127562 & Cichorium intybus & Chile & - & JX546746 & JX546889 & JX546650 \\
\hline C. nupharicola & $\begin{array}{l}\text { CBS 470.96, ICMP } \\
18187\end{array}$ & $\begin{array}{l}\text { Nuphar lutea subsp. } \\
\text { polysepala }\end{array}$ & USA & - & JX009972 & JX010398 & JX009437 \\
\hline \multirow[t]{3}{*}{ C. nymphaeae } & CBS 119294 & Leucaena sp. & Mexico & - & JQ948535 & JQ949856 & JQ949526 \\
\hline & CBS 515.78 & Nymphaeae alba & Netherlands & _- & JQ948527 & JQ949848 & JQ949518 \\
\hline & $19 / 27^{*}$ & $\begin{array}{l}\text { Campanula } \\
\text { rapunculoides }\end{array}$ & Italy & M & MN551611 & MN551609 & MN551610 \\
\hline C. ocimi & CBS 298.94 & Ocimum basilicum & Italy & - & KM105577 & KM105502 & KM105432 \\
\hline C. theobromicola & ICMP $18649^{\mathrm{T}}$ & Theobroma cacao & Panama & - & JX010006 & JX010447 & JX009444 \\
\hline C. vignae & CBS 501.97 & Vigna unguiculata & Nigeria & - & KM105534 & KM105463 & KM105393 \\
\hline $\begin{array}{l}\text { Moniolochaetes } \\
\text { infuscans }\end{array}$ & CBS 869.96 & Ipomoea batatas & South Africa & - & JX546612 & JQ005864 & JQ005843 \\
\hline
\end{tabular}

${ }^{1}$ ATCC: American Type Culture Collection, Virginia, USA; CBS: Westerdijk Fungal Biodiversity Institute, Utrecht, the Netherlands; CGMCC: China General Microbiological Culture Collection Center, Beijing, China; CVG: Agroinnova, Grugliasco, Torino, Italy; COAD: Coleção Octávio Almeida Drummond, Viçosa, Brazil; ICMP: International Collection of Microorganisms from Plants, Landcare Research, Auckland, New Zealand; IMI: Culture collection of CABI Europe UK Centre, Egham, UK; LC = working collection of Lei Cai, CAS, China. Ex-type and ex-epitype cultures are indicated with T.

${ }^{2}$ gapdh: glyceraldehyde-3-phosphate dehydrogenase gene; tub2: beta-tubulin gene; act: actin gene. Sequences generated in this study indicated in italics.

*Isolates used for pathogenicity experiments and morphology description.

\section{Results}

\section{Field surveys and fungal isolation}

Typical anthracnose symptoms caused by Colletotrichum spp. were found on different ornamental hosts (Table 1) and were identified as those caused by Colletotrichum spp. Disease incidence was established considering the percentage of affected leaves and varied from 15 to $40 \%$, depending on environmental conditions and the species of the host plants.

Symptoms were detected on leaves of $\mathrm{Ca}$. rapunculoides, Cor. lanceolata M. aquifolium Ca. trachelium, Ce. thyrsiflorus, $H$. paniculata, L. styraciflua on plants grown outdoors in a private garden, and on different cultivars of
$C y$. persicum and $R$. jasminoides grown in nursery at temperature from 18 to $28^{\circ} \mathrm{C}$.

Brown to black necrotic lesions were observed on leaves on all the investigated host species. On Ca. trachelium, the first symptoms consisted of as small, circular spots, subsequently becoming irregular, expanded to dark lesions surrounded by a chlorotic halo. Chlorotic leaves with light brown, irregular necrotic spots were detected, along with affected petioles on 7-8 month-old plants of Ca. rapunculoides. All the affected tissues rotted and became dry. Leaf blight with black, irregular necrosis with a well-defined margin that expanded up was observed on Co. lanceolata. Whilst, circular brown spots with chlorotic halo developing at margin were observed on cyclamen, as well as on blueblossom plants. 
Brown necrotic lesions, $10-60 \mathrm{~mm}$ in diameter, with dark irregular margin were found on 30 years old plants of L. styraciflua. Warm temperature and HR promoted the development and the spread of the lesions. Regarding H. paniculata, initial pale brown irregular lesions were observed on the apical leaf margin that subsequently spread covering the entire leaf surface. On M. aquifolium were observed irregularly circular, brown, slightly sunken, necrotic lesions surrounded by a chlorotic halo. Lesions enlarged up to $10 \mathrm{~mm}$ in diameter and eventually coalesced. Small dark brown necrotic spots were detected on leaves of 2-year-old plants of $R$. jasminoides cultivated in commercial nursery.

\section{Phylogenetic analyses}

Four alignments were analysed representing single gene analyses of act, gapdh, tub2 and a combined alignment of the three genes. The alignments produced topologically similar trees. The combined species phylogeny of the Colletotrichum isolates consisted of 63 sequences, including the outgroup sequences of Moniolochaetes infuscans (CBS 896.96).

A total of 1065 characters (gapdh: 1-308, act: 315-611, tub2: 618-1065) were included in the phylogenetic analysis, 521 characters resulted as parsimony-informative, 148 as variable and parsimony-uninformative, and 384 were constant. A maximum number of 1000 equally most parsimonious trees were saved (Tree length $=1846, \mathrm{CI}=0.660, \mathrm{RI}=0.933$ and $\mathrm{RC}=0.616$ ). Bootstrap support values obtained with the parsimony analysis are showed on the Bayesian phylogenies in Fig. 1. For the Bayesian analyses, the dirichlet state frequency distributions were suggested by MrModeltest for analysing all the partitions. The following models, recommended by MrModeltest, were used: HKY $+\mathrm{G}$ for $a c t$, and GTR $+\mathrm{G}$ for gapdh and tub2. In the Bayesian analysis, the gapdh partition had 268 unique site patterns, the act partition had 179 unique site patterns, the $t u b 2$ partition had 216 unique site patterns and the analysis ran for 1.295 .000 generations, resulting in 2592 trees of which 1944 trees were used to calculate the posterior probabilities. In the combined analyses twelve isolates (seven from $C y$. persicum, three from L. styraciflua and two from $H$. paniculata) clustered with two reference strains and the ex-type of Col. fructicola, whilst one isolate from $L$. styraciflua and two isolates from $R$. jaminoides were identified as Col. cigarro and Col. grossum, respectively. Three isolates from Ca. trachelium clustered with the epitype of $\mathrm{Col}$. lineola. Three isolates from M. aquifolium, Ca. rapunculoides and Cor. lanceolata were identified as Col. fioriniae, Col. nymphaeae and Col. fuscum, respectively.

\section{Morphology}

Morphological observations, supported by phylogenetic inference, were used to characterize the six known species described below. Culture characteristics were observed and the colour of upper and lower surfaces of Petri dishes assessed.

\section{Colletotrichum fioriniae}

Asexual morph on PDA. Conidiomata acervular. Hyphae hyaline, septate and branched. Setae not observed. Conidia hyaline, ellipsoid with rounded ends, with guttulae, produced in abundance after 10 days growing on media. Conidia size (mean $\pm \mathrm{SD}$ ): $13.03 \pm 1 \times 4.5 \pm 0.6 \mu \mathrm{m}$. Culture characteristics - colonies velvety to cottony and flat with salmon-like coloured in the centre to pale grey and white at the margin mycelium. Orange spore masses. Reverse orange - pale brown to white at the margin. Colony diameter: $68-68 \mathrm{~mm}$ in $10 \mathrm{~d}$.

\section{Colletotrichum fructicola}

Asexual morph on PDA. Conidiomata acervular. Hyphae hyaline, septate and branched. Setae not observed. Conidia hyaline, ellipsoid with rounded ends, with guttulae, produced in abundance after 10 days growing on media. Conidia size (mean $\pm \mathrm{SD}$ ): $16.3 \pm 1.6 \times 4.9 \pm 0.6 \mu \mathrm{m}$. Culture characteristics - flat colonies cottony to floccose with entire margin, white - light grey mycelium. Reverse black with a pale circle at the margin. Colony diameter: $85-85 \mathrm{~mm}$ in $10 \mathrm{~d}$.

\section{Colletotrichum fuscum}

Asexual morph on PDA. Conidiomata acervular. Hyphae hyaline, septate and branched. Setae not observed. Conidia hyaline, cylindrical to ellipsoid with rounded ends, with guttulae, produced in abundance after 10 days growing on media. Conidia size (mean $\pm \mathrm{SD}$ ): $16.8 \pm 2.5 \times 4.0 \pm 0.4 \mu \mathrm{m}$. Culture characteristics - colonies velvety to powdery and flat black colored in the center to pale grey and with white margin. Black spore masses. Reverse dark grey to light gray at the margin. Colony diameter: $64-63 \mathrm{~mm}$ in $10 \mathrm{~d}$.

\section{Colletotrichum grossum}

Asexual morph on PDA. Conidiomata acervular. Hyphae hyaline, septate and branched. Setae not observed. Conidia hyaline, cylindrical to ellipsoid with rounded ends, with guttulae, produced in abundance after 10 days growing on media. Conidia size (mean $\pm \mathrm{SD}$ ): $17.3 \pm 1.5 \times 4.6 \pm 0.6 \mu \mathrm{m}$. Culture characteristics - colonies velvety to cottony and flat with dark to pale grey mycelium. Orange spore masses. Reverse black to pale grey. Colony diameter: $90-90 \mathrm{~mm}$ in $10 \mathrm{~d}$. 
Fig. 1 Consensus phylogram resulting from a Bayesian analysis of the combined gapdh, act and tub2 sequences of Colletotrichum spp. Bayesian posterior probability values and Bootstrap support values are indicated at the nodes. Colletotrichum species complexes are on the left. The strains collected and species found in this study are in red. The tree was rooted to

Moniolochaetes infuscans (CBS 869.96)

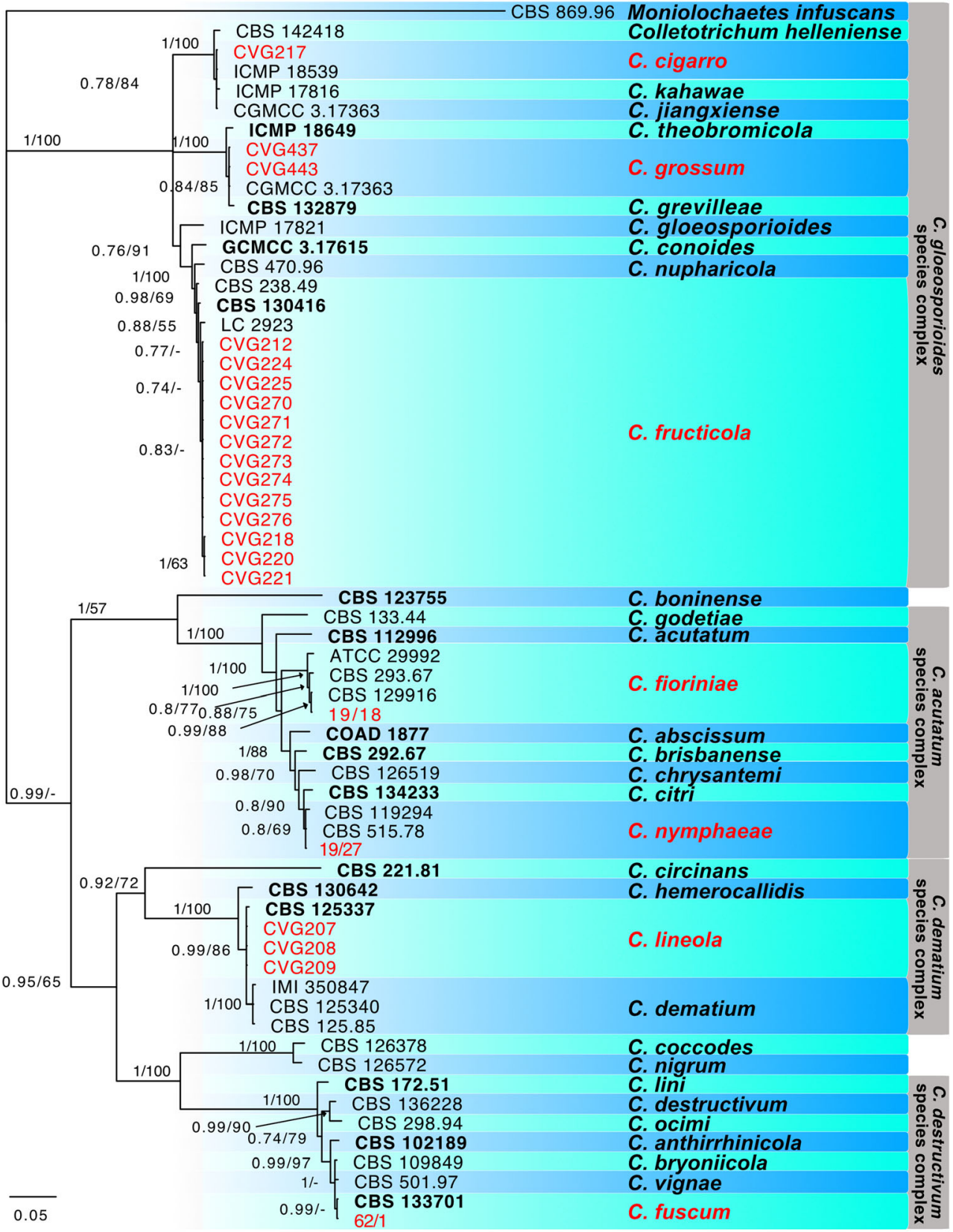

\section{Colletotrichum cigarro}

Asexual morph on PDA. Conidiomata acervular. Hyphae hyaline, septate and branched. Setae not observed. Conidia hyaline, ellipsoid with rounded ends, with guttulae, produced in abundance after 10 days growing on media. Conidia size $($ mean $\pm \mathrm{SD})$ : $15.4 \pm$ $1 \times 6.0 \pm 0.6 \mu \mathrm{m}$. Culture characteristics - colonies velvety to cottony and flat with grey mycelium. Orange spore masses. Reverse pale grey. Colony diameter: 90 $90 \mathrm{~mm}$ in $10 \mathrm{~d}$.

\section{Colletotrichum lineola}

Asexual morph on PDA. Conidiomata acervular. Hyphae hyaline, septate and branched. Setae not observed. Conidia hyaline, curved with ends, with guttulae, produced in abundance after 7 days growing on media. Conidia size $($ mean $\pm \mathrm{SD}): 27.0 \pm 1.7 \times 3.6 \pm 0.4 \mu \mathrm{m}$. Culture characteristics - colonies velvety and flat with dark to pale grey and yellowish at the margin mycelium. Reverse pale brown with yellow halo at the margin. Colony diameter: $55-45 \mathrm{~mm}$ in $10 \mathrm{~d}$. 


\section{Colletotrichum nymphaeae}

Asexual morph on PDA. Conidiomata acervular. Hyphae hyaline, septate and branched. Setae not observed. Conidia hyaline, ellipsoid with rounded ends, with guttulae, produced in abundance after 7 days growing on media. Conidia size (mean $\pm \mathrm{SD}$ ): $13.7 \pm 1 \times 4.5 \pm 0.6 \mu \mathrm{m}$. Culture characteristics - colonies velvety and flat with salmon-like coloured in the centre to pale grey and black at the margin mycelium. Orange spore masses. Reverse orange to pale grey. Colony diameter: $67-67 \mathrm{~mm}$ in $10 \mathrm{~d}$.

\section{Pathogenicity}

All the tested isolates revealed to be pathogenic to the original hosts inoculated only through simulation of wounded leaves conditions. The disease symptoms were comparable to those observed in the field at the beginning of this survey (Fig. 2), they consisting of dark brown to black necrotic spots and lesions. The Colletotrichum species aggressiveness varied based on the pathogen/host association (Table 1).

The identity of the re-isolated fungi was confirmed by sequencing the gapdh locus and Koch's postulates were fulfilled. No symptoms have developed on the control and unwounded plants.

\section{Discussion}

Species of Colletotrichum were recovered with a frequency of $70 \%$ from leaf tissues with typical symptoms of anthracnose of the different host species. The diversity of Colletotrichum spp. associated with ornamental plants in northern Italy and their aggressiveness were investigated in this study. Fungal species were identified based on the polyphasic approach promoted by Cai et al. (2009), which demonstrated that traditional morphological characters alone are considered not reliable anymore for the identification of Colletotrichum species. Thus, multilocus sequence analyses, combined with morphological and pathogenic data, have become the most used characterization tool.

This study is based on a robust multi-locus phylogeny established on three genomic loci. Currently, the ITS region is the most widely sequenced region, however, according to Crouch et al. (2009), the currently available ITS sequence data of Colletotrichum spp. could lead to unreliable identifications. Thus, ITS locus was not considered in the present work and the loci gapdh, act and tub2 were combined and analysed with previous phylogenetic analyses of the genus Colletotrichum (Damm et al. 2012a, b; 2014; Guarnaccia et al. 2017). The characterization revealed a diversity in the composition of Colletotrichum spp. associated with ornamental host plants.
Twenty-two strains were characterized as seven different species: Col. fioriniae and Col. nymphaeae belonging to the Col. acutatum SC, Col. fuscum belonging to the Col. destructivum $\mathrm{SC}$, Col. lineola within the Col. dematium SC and Col. fructicola, Col. cigarro and Col. grossum into the Col. gloeosporioides SC.

Col. fioriniae and Col. nymphaeae were found in association with M. aquifolium and Ca. rapunculoides, respectively. Col. fuscum and Col. lineola were isolated from leaf spots on Cor. lanceolata and Ca. trachelium, respectively. Whilst, Col. cigarro and Col. grossum caused necrotic lesions on $L$. styraciflua and R. jasminoides, respectively. Moreover, Col. fructicola was isolated from leaves of L. styraciflua and $H$. paniculata and stems and leaves of Cy. persicum. The association between Col. fioriniae and M. aquifolium and Col. cigarro and L. styraciflua, were reported on the base of a minor number of locus-sequencing (Garibaldi et al. 2016; 2020), thus this study confirms the identification of $\mathrm{Col}$. fioriniae as pathogen of M. aquifolium and clarifies the identity of Col. cigarro as pathogen of L. styraciflua. Necrotic spots, round to oval spots with a purple margin irregularly spreading to the entire leaf, brownish anthracnose lesions or streaks often interesting the margins of the leaves and premature leaf fall, were observed.

Col. fioriniae and Col. nymphaeae belong to the same SC and they can be separated by analysis of the tub2 gene (Damm et al. 2012b). Colletotrichum fioriniae was described on Fiorinia externa (a scale insect) and widely reported as an endophyte (Marcelino et al. 2008) and as a worldwide distributed pathogen causing rot on several fruit such as almond, apple, avocado, blueberry, cranberry, mango, nectarine and pepper (Damm et al. 2012a; Freeman and Shabi 1996). Recently, Col. fioriniae has been found in association with Origanum vulgare and Salvia leucantha in Italy (Guarnaccia et al. 2019), demonstrating its established presence in this territory and the ability to cause disease on diverse hosts. Col. nymphaeae is known as pathogen on different hosts, such as Anemone spp., Capsicum spp., Fragaria $\times$ ananassa, Malus domestica and Vitis vinifera (Jayawardena et al. 2016), in Italy is known as a major pathogen of olive (Antelmi et al. 2019), however it was never reported on Campanula spp.

Colletotrichum fuscum can be distinguished from other species in the Col. destructivum SC by gapdh sequence data and it was found in association with Digitalis sp. in Germany and The Netherlands (Damm et al. 2014). Col. lineola, the type species of the genus Colletotrichum, is widespread on temperate regions, mostly found on cereals (Damm et al. 2009). To our knowledge, this is the first report of Col. lineola in Italy and as pathogen of Campanula spp. Colletotrichum kahawae subsp. cigarro has been described as a species with a wide host range and distribution by Weir et al. (2012). Batista et al. (2016) considered this species, along with Col. kahawae 
Fig. 2 Symptoms caused by Colletotrichum spp. observed in the field $(\mathbf{a}, \mathbf{b}, \mathbf{c}, \mathbf{d}, \mathbf{e}, \mathbf{f}, \mathbf{g})$ and after pathogenicity trials $(\mathbf{h}, \mathbf{i}, \mathbf{j}, \mathbf{k})$ on leaves of different ornamental plants. (a) Cyclamen persicum, (b) Coreopsis lanceolata, (c, $\mathbf{j})$ Liquidambar styraciflua, (d) Campanula rapunculoides, (e) Mahonia aquifolium, (f, $\mathbf{g}, \mathbf{h})$ Hydrangea paniculata, $(\mathbf{i})$ Rhyncospermum jasminoides, (k) Ceanothus thyrsiflorus
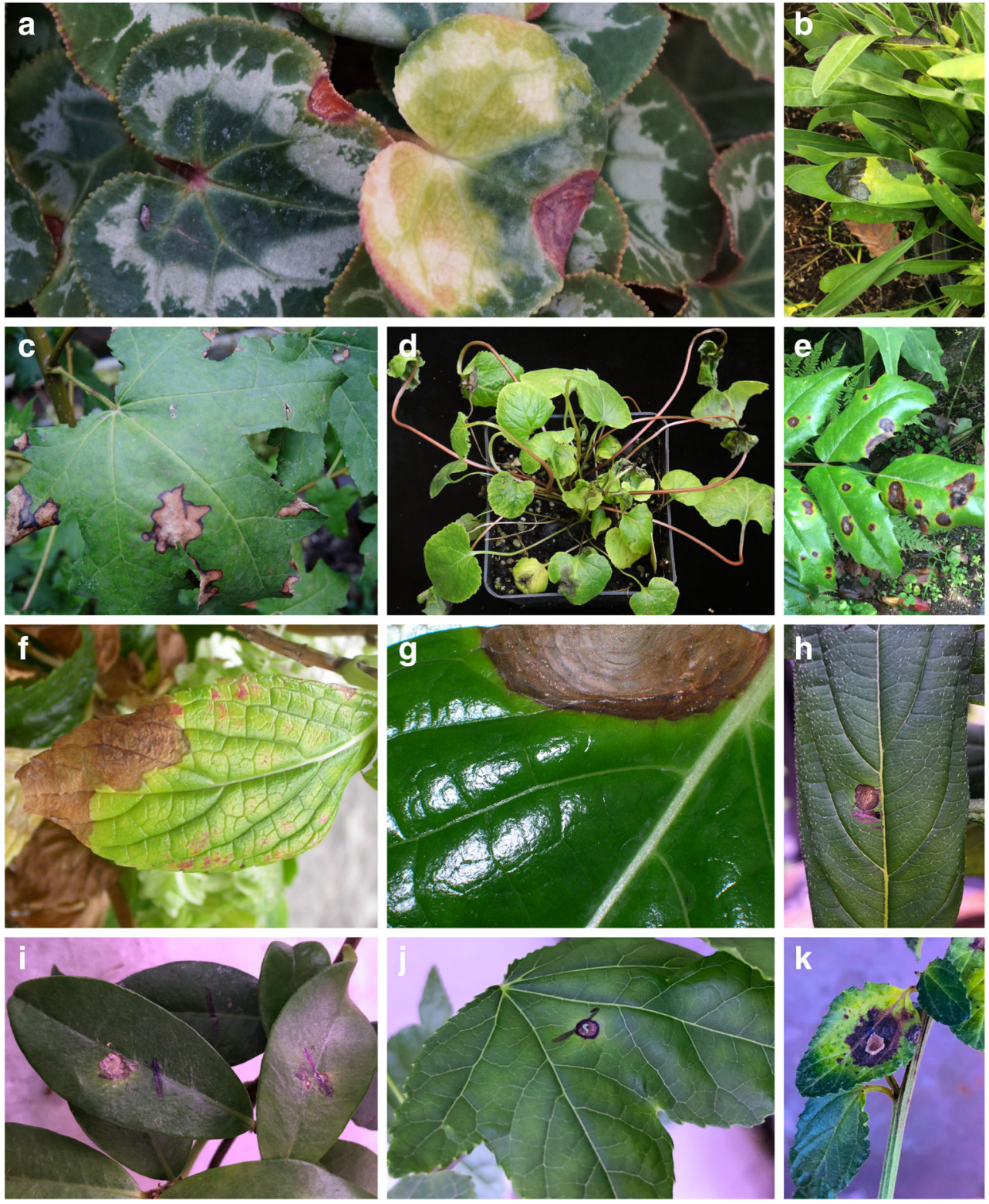

subsp. kahawae, as cryptic. However, the analysis conducted in this study permitted to identify the strain as Col. cigarro through the comparison of nucleotide sequences with other species belonging to the same clade, according with the recent description of new combination by Cabral et al. (2020). This species was reported in Italy on mandarin (Perrone et al. 2016) and in other European countries on Camellia and Olea plants (Cabral et al. 2020).

Colletotrichum grossum is reported as pathogen on Capsicum annuum var. grossum in China (Diao et al. 2017) and it was detected on mango leaves in Cuba (Manzano León et al. 2018). It can be distinguished with the use of gapdh, act and tub2 sequence data from Col. theobromicola (Jayawardena et al. 2016). This study represents the first founding of this species in Italy. Isolates of Col. fructicola worldwide distributed are biologically different. They were recovered from Coffea, Pyrus pyrifolia, Limonium, Malus domestica and Fragaria x ananassa, Persea Americana, Ficus, Dioscorea, Theobroma and Tetragastris in Thailand, Japan, Israel, USA, Australia, Germany, Nigeria and Panama, respectively (Weir et al. 2012). Recently, it was reported in Italy as causing fruit rot of avocado (Guarnaccia et al. 2016) and leaf spots on Salvia greggii (Guarnaccia et al. 2019). Moreover, it was identified among the new pathogens of Malus domestica by the EPPO (2018) and it was inserted in the EPPO alert list within pests with high economic importance and more likely to transfer.

Although with different levels of aggressiveness, all the tested strains revealed to be pathogenic. For example, Col. fructicola showed variability in severity of anthracnose 
causing on different host, producing relevant infection on $\mathrm{Ce}$. thyrsiflorus and $C y$. persicum, but not on $H$. paniculata. It is imperative at this stage to consider the pathogenicity results as preliminary, and further studies should be conducted in future to assess the putative cross pathogenicity and the role of plant tissue wounds for the symptoms development. Moreover, other pathogens were reported after several surveys in the same territory of northern Italy on the host plants considered in this study, demonstrating that several emerging and wellestablished pathogens can represent a threat for the cultivation of these plants (Gullino et al. 2015; Garibaldi et al. 2017).

Greenhouse and nursery environments could induce suitable conditions for the development of pathogens and, particularly, of diseases caused by Colletotrichum which sporulation and spread are easily promoted with high temperature and humidity (Washington et al. 2006). Thus, considering the relevance of this sector and the susceptibility of these crops to several pathogens, it is important to provide a correct pest diagnosis for an accurate and effective disease management. Since classification of pests are the basis to any further studies on plant and fruit disease as they represent a key-role in pathogen control, this work could provide useful tools to analyse target loci for a fast detection of species within Colletotrichum genus. Future studies will focus on detailed experiments to deeply investigate pathogenicity and epidemiological aspects.

Acknowledgement Open access funding provided by Università degli Studi di Torino within the CRUI-CARE Agreement. This work was funded by the Ministry of Education, Universities and Research (MIUR), Local research (ex 60\%).

\section{Compliance with ethical standards}

Conflict of interest The Authors declare that they have no conflict of interest. This article does not contain any studies with animals performed by any of the authors. This article does not contain any studies with human participants or animals performed by any of the authors.

Open Access This article is licensed under a Creative Commons Attribution 4.0 International License, which permits use, sharing, adaptation, distribution and reproduction in any medium or format, as long as you give appropriate credit to the original author(s) and the source, provide a link to the Creative Commons licence, and indicate if changes were made. The images or other third party material in this article are included in the article's Creative Commons licence, unless indicated otherwise in a credit line to the material. If material is not included in the article's Creative Commons licence and your intended use is not permitted by statutory regulation or exceeds the permitted use, you will need to obtain permission directly from the copyright holder. To view a copy of this licence, visit http://creativecommons.org/licenses/by/4.0/.

\section{References}

Antelmi I, Sion V, Nigro F (2019) First Report of Colletotrichum nymphaeae on Olive in Italy. Plant Dis 103:765-765
Batista D, Silva DN, Vieira A, Cabral A, Pires AS et al (2016) Legitimacy and implications of reducing Colletotrichum kahawae to subspecies in plant pathology. Front Plant Sci 7:2051

Brand MH, Lineberger RD (1992) Micropropagation of American Sweetgum (Liquidambar styraciflua L.). In: Bajaj YPS (ed) HighTech and Micropropagation II. Biotechnology in Agriculture and Forestry, vol 18. Springer, Berlin, pp 3-24

Cabral A, Azinheira HG, Talhinhas P, Batista D, Ramos AP, Silva MDC Oliveira H, Várzea V (2020) Pathological, morphological, cytogenomic, biochemical and molecular data support the distinction between Colletotrichum cigarro comb. et stat. nov. and Colletotrichum kahawae. Plants 9:502

Cai L, Hyde KD, Taylor PWJ, Weir BS, Waller J, Abang MM, Zhang JZ, Yang YL, Phoulivong S, Liu ZY, Prihastuti H, Shivas RG, McKenzie EHC, Johnston PR (2009) A polyphasic approach for studying Colletotrichum. Fungal Divers 39:183-204

Camele I, Mang SM, Elshafie HS, Frisullo S (2018) First report of Colletotrichum acutatum causing anthracnose on Feijoa sellowiana in Italy. Plant Dis 102:1850

Cannon PF, Buddie AG, Bridge PD (2008) The typification of Colletotrichum gloeosporioides. Mycotaxon 104:189-204

Cannon PF, Damm U, Johnston PR, Weir BS (2012) Colletotrichum current status and future directions. Stud Mycol 73:181-213

Carbone I, Kohn LM (1999) A method for designing primer sets for speciation studies in filamentous ascomycetes. Mycologia 91:553556

Chase AR, Daughtrey ML, Cloyd RA (2018) Compendium of bedding plant diseases and pests. American Phytopathological Society, St. Paul

Croci A (2018) Italian horticulture in FloraCulture International, published by AIPH

Crouch JA, Clarke BB, Hillman BI (2009) What is the value of ITS sequence data in Colletotrichum systematics and species diagnosis? A case study using the falcate-spored graminicolous Colletotrichum group. Mycologia 101:648-656

Damm U, Woudenberg JHC, Cannon PF, Crous PW (2009) Colletotrichum species with curved conidia from herbaceous hosts. Fungal Divers 39:45-87

Damm U, Cannon PF, Woudenberg JHC, Crous PW (2012a) The Colletotrichum acutatum species complex. Stud Mycol 73:37-113

Damm U, Cannon PF, Woudenberg JHC, Johnston PR, Weir BS, Tan YP, Shivas RG, Crous PW (2012b) The Colletotrichum boninense species complex. Stud Mycol 73:1-36

Damm U, Cannon PF, Liu F et al (2013) The Colletotrichum orbiculare species complex: Important pathogens of field crops and weeds. Fungal Divers 61:29-59

Damm U, O'Connell RJ, Groenewald JZ, Crous PW (2014) The Colletotrichum destructivum species complex-hemibiotrophic pathogens of forage and field crops. Stud Mycol 79:49-84

De Silva DD, Crous PW, Ades PK, Hyde KD, Tylor PWJ (2017) Life styles of Colletotrichum species and implications for plant biosecurity. Fungal Biol Rev 31:155-168

Dean R, Van Kan JAL, Pretorius ZA, Hammond-Kosack KE, Di Pietro A, Spanu PD, Rudd JJ, Dickman M, Kahmann R, Ellis J et al (2012) The top 10 fungal pathogens in molecular plant pathology. Mol Plant Pathol 13:414-430

Diao YZ, Zhang C, Liu F, Wang WZ, Liu L, Cai L, Liu XL (2017) Colletotrichum species causing anthracnose disease on chili in China. Persoonia 38:20-37

EPPO European and Mediterranean Plant Protection Organization (2018) DROPSA project EU FP7

Freeman S, Shabi E (1996) Cross-infection of subtropical and temperate fruits by Colletotrichum species from various hosts. Physiol Mol Plant P 49:395-404 
Garibaldi A, Gilardi G, Franco Ortega S, Gullino ML (2016) First report of leaf spot caused by Colletotrichum kahawae on American sweetgum (Liquidambar styraciflua) in Italy. J Plant Pathol 98:370

Garibaldi A, Bertetti D, Rapetti S, Gullino ML (2017) Malattie delle piante ornamentali. Edagricole, Milano

Garibaldi A, Bertetti D, Matić S, Luongo I, Guarnaccia V, Gullino ML (2020) First report of leaf blight caused by Colletotrichum fioriniae on Mahonia aquifolium in Italy. Plant Dis 104:983

Gilardi G, Ortu G, Franco Ortega S, Gullino ML, Garibaldi A (2015) New Colletotrichum spp. on ornamental plants in Northern Italy. J Plant Pathol 97:33

Glass NL, Donaldson G (1995) Development of primer sets designed for use with PCR to amplify conserved genes from filamentous ascomycetes. Appl Environ Microbiol 61:1323-1330

Guarnaccia V, Aiello D, Polizzi G, Perrone G, Stea G, Vitale A (2014) Emergence of prochloraz-resistant populations of Calonectria pauciramosa and Calonectria polizzii in ornamental nurseries of Southern Italy. Plant Dis 98:344-350

Guarnaccia V, Vitale A, Cirvilleri G, Aiello D, Susca A, Epifani F, Perrone G, Polizzi G (2016) Characterisation and pathogenicity of fungal species associated with branch cankers and stem-end rot of avocado in Italy. Eur J Plant Pathol 146:963-976

Guarnaccia V, Groenewald JZ, Polizzi G, Crous PW (2017) High species diversity in Colletotrichum associated with citrus diseases in Europe. Persoonia 39:32-50

Guarnaccia V, Gilardi G, Martino I, Garibaldi A, Gullino ML (2019) Species diversity in Colletotrichum causing anthracnose of aromatic and ornamental Lamiaceae in Italy. Agronomy 9:613

Guerber JC, Liu B, Correll JC, Johnston PR (2003) Characterization of diversity in Colletotrichum acutatum sensu lato by sequence analysis of two gene introns, mtDNA and intron RFLPs, and mating compatibility. Mycologia 95:872-895

Gullino ML, Garibaldi A (2007) Critical aspects in management of fungal diseases of ornamental plants and directions in research. Phytopathol Mediterr 46:135-149

Gullino ML, Daughtrey ML, Garibaldi A, Elmer WH (2015) Fusarium wilts of ornamental crops and their management. Crop Prot 73:50 59

Hillis DM, Bull JJ (1993) An empirical test of bootstrapping as a method for assessing confidence in phylogenetic analysis. Syst Biol 42:182192

Jayawardena RS, Hyde KD, Damm U, Cai L, Liu M, Li XH, Zhang W, Zhao WS, Yan JY (2016) Notes on currently accepted species of Colletotrichum. Mycosphere 7:1192-1260

Katoh K, Standley DM (2013) MAFFT Multiple sequence alignment software version 7: Improvements in performance and usability. Mol Biol Evol 30:772-780

Kumar S, Stecher G, Tamura K (2016) MEGA7: Molecular Evolutionary Genetics Analysis version 7.0 for bigger data-sets. Mol Biol Evol 33:1870-1874

Lancaster N, Wesley W (2008) Hydrangea paniculata. R Hortic Soc Bull 23
Lee HB (2012) First report of powdery mildew caused by Erysiphe arcuate on lanceleaf coreopsis (Coreopsis lanceolata) in Korea. Plant Dis 96:1827

Manzano León AM, Serra Hernandéz W, García Pérez L et al (2018) First report of leaf anthracnose caused by Colletotrichum grossum on mango (Mangifera indica) in Cuba. J Plant Pathol 100:329

Marcelino J, Giordano R, Gouli S et al (2008) Colletotrichum acutatum var. fioriniae (teleomorph: Glomerella acutata var. fioriniae var. nov.) infection of a scale insect. Mycology 100:353-374

Marin-Felix Y, Groenewald JZ, Cai L, Chen Q, Marincowitz S, Barnes I, Bensch K, Braun U, Camporesi E, Damm U et al (2017) Genera of phytopathogenic fungi: GOPHY 1. Stud Mycol 86:99-216

Nylander JAA (2004) MrModeltest v. 2. Programme Distributed by the Author; Evolutionary Biology Centre. Uppsala University, Uppsala

O'Connell RJ, Thon MR, Hacquard S et al (2012) Lifestyle transitions in plant pathogenic Colletotrichum fungi deciphered by genome and transcriptome analyses. Nat Genet 44:1060-1065

O’Donnell K, Cigelnik E (1997) Two divergent intragenomic rDNA ITS2 types within a monophyletic lineage of the fungus Fusarium are nonorthologous. Mol Phylogenet Evol 7:103-116

Perrone G, Magistà D, Ismail AM (2016) First report of Colletotrichum kahawae subsp. ciggaro on mandarin in Italy. J Plant Pathol 98:12

Polizzi G, Aiello D, Guarnaccia V, Vitale A, Perrone G, Stea G (2011) First report of damping-off on strawberry tree caused by Colletotrichum acutatum and C. simmondsii in Italy. Plant Dis 95: 1588

Ronquist F, Teslenko M, van der Mark P, Ayres DL, Darling A, Höhna S, Larget B, Liu L, Suchard MA, Huelsenbeck JP (2012) MrBayes 3.2: Efficient Bayesian phylogenetic inference and model choice across a large model space. Syst Biol 61:539-542

Scariot V, Seglie L, Gaino W, Devecchi M (2012) Evaluation of european native bluebells for sustainable floriculture. Acta Hortic 937:273279

Schmidt CL (2006) Review of Ceanothus. Nativ Plants J 7:151-152

Shivas RG, Tan YP (2009) A taxonomic reassessment of Colletotrichum acutatum introducing $C$. fioriniae comb. et stat. nov. and C. simmondsii sp. nov. Fungal Divers 39:111-122

Swofford DL (2003) Phylogenetic analysis using parsimony (and Other Methods), v. 4.0b10. Sinauer Associates, Sunderland

Takamura T (2007) Cyclamen. In: Anderson NO (ed) Flower breeding and genetics. Springer, Dordrecht, pp 459-478

Udayanga D, Manamgoda DS, Liu X et al (2013) What are the common anthracnose pathogens of tropical fruits? Fungal Divers 61:165-179

Washington WS, Irvine G, Aldaoud R, De Alwis S, Edwards J, Pascoe IG (2006) First record of anthracnose of spinach caused by Colletotrichum dematium in Australia. Australas. Plant Pathol 35: 89-91

Weaver RE, Anderson PJ (2012) Jasmine, a diversity of plants with fragrant flowers. Bot Circ 38

Weir BS, Johnston PR, Damm U (2012) The Colletotrichum gloeosporioides species complex. Stud Mycol 73:115-180 